\title{
Mesleki Grup Rehberliği Programına Katılan Lise Öğrencilerinin Mesleki Kararsızlık Düzeylerinin İncelenmesi
}

\author{
Mehmet Ali ÇAKIR ${ }^{1} \quad$ Kıvanç UZUN ${ }^{2}$
}

Gönderim Tarihi: 16.04 .2021

Kabul Tarihi: 08.09.2021

Öz: Bu araştırmada, mesleki kararsızlık düzeyini azaltmaya yönelik geliştirilmiş olan mesleki grup rehberliği programının onuncu sınıf öğrencileri üzerindeki etkililiği sınanmıştır. Araştırma, deney ve kontrol gruplu, ön-test, sontest ve izlem ölçümlü, deneme koşullarından ise karışık desenin kullanıldığı yarı deneysel bir çalışmadır. Araştırmanın çalışma grubunu, Muğla - Bodrum'da yer alan bir Anadolu lisesinin onuncu sınıfında öğrenim görmekte olan kırk öğrenci oluşturmaktadır. Araştırmada veri toplama aracı olarak Mesleki Karar Envanteri kullanılmıştır. Mesleki Karar Envanterinin ön-test uygulamasından düşük puan alan kırk öğrenci, deneklerin eşleştirilmesi yöntemiyle deney ve kontrol gruplarına atanmıştır. Deney grubunda yer alan öğrencilere on hafta boyunca, mesleki kararsızlık düzeylerini azaltmaya yönelik mesleki grup rehberliği programı uygulanmıştır. Kontrol grubunda yer alan öğrencilere ise herhangi bir müdahale yapılmamıştır. Araştırmanın sonunda mesleki grup rehberliği programına katılan onuncu sınıf öğrencilerinin mesleki kararsızlık puanları anlamlı bir şekilde farklılık göstermiştir. Öğrencilerin mesleki kararsızlık puanları üzerindeki bu farklılık, kırk beş gün sonra yapılan izlem ölçümlerinde de kalıcılığını korumuştur. Araştırmanın bulguları ilgili alanyazın ışı̆̆ında tartışılmıştır.

Anahtar Kelimeler: Grup rehberliği, Lise öğrencisi, Mesleki karar verme, Mesleki kararsızlık.

\section{Investigation of Occupational Indecisiveness Levels of High School Students Participating in the Occupational Group Guidance Program}

\begin{abstract}
In the current study, the effectiveness of an occupational group guidance program developed to reduce the level of occupational indecisiveness on tenth grade students was tested. The research is a quasi-experimental study with experimental and control groups, with pre-test, post-test and follow-up measurements, and in the experimental conditions, mixed design is used. The study group of the research consists of forty students studying in the tenth grade of an Anatolian high school located in the Bodrum district of Muğla. The data of the study were collected the Occupational Decision Inventory. Forty students who received low scores from the pre-test application of the Occupational Decision Inventory were assigned to experimental and control groups through the method of equating. The experimental group students were subjected to the occupational group guidance program to reduce their level of occupational indecisiveness for ten weeks. No study was conducted with the control group students. In the end of the study, the occupational indecisiveness scores of the tenth grade students who participated in the occupational group guidance program differed significantly. This difference in the occupational indecisiveness scores of the students maintained its persistence in the follow-up measurements made after forty five days. The findings of the study were discussed in light of the related literature.
\end{abstract}

Keywords: Group counselling, High school student, Occupational decision making, Occupational indecisiveness.

\section{Gíriş}

Teknolojinin gelişmesi, sanayileşme ve işgücü piyasasındaki çeşitlilik meslek seçimini giderek daha zor ve karmaşık bir süreç haline getirmektedir. Bu nedenle meslek seçimi konusunda öğrencilerine yardımcı olmak, okul psikolojik danışmanları ve eğitim psikologları için yeni zorluklar anlamina gelmektedir. En uygun mesleği seçmek için öğrencilerin, tüm seçenekleri ve fırsatları değerlendirebilecek yeterliğe ulaşmaları gerekmektedir (Luzzo, 1993). Bu bağlamda öğrencilerin, meslek seçimi sürecinde mümkün olan en bilinçli hale gelebilmeleri için desteğe

\footnotetext{
${ }^{1}$ Burdur Mehmet Akif Ersoy Üniversitesi, Türkiye, macakir@mehmetakif.edu.tr, ORCID: 0000-0001-9288-2175

2 Burdur Mehmet Akif Ersoy Üniversitesi, Türkiye, kuzun@mehmetakif.edu.tr, ORCID: 0000-0002-6816-1789
} 
ihtiyaç duymaları kaçınılmazdır. Bilinçli bir meslek seçim süreci yaşamak, bir mesleğe yönelik karar kılmak için oldukça iyi bir başlangıç noktasıdır.

\section{Kavramsal Çerçeve}

\section{Mesleki Karar Verme ve Kararsızlık}

Bir mesleğe karar kılmak, bireyin gelişiminin ve kişisel mutluluğunun en önemli yönlerinden biri olarak gösterilmektedir (Sharf, 2013). Diğer yandan mesleki kararsızlık ise bireyin yaşam değerlerinden yaşayacağı yere kadar çeşitli sorunları etkileyen bir süreç olarak ifade edilmektedir (Akkoç, 2012a). Mesleki kararsızlık özellikle lise öğrencileri için ortak bir sorundur; ancak çalışanlar için de muhtemel bir sorun olma ihtimalini her zaman içerisinde saklar. Bireylerin, sadece erken yaşlarda, geç ergenlik döneminde ve yetişkinlikte bir meslek kararı vermesi yeterli değildir; aksine bireyler, her yaşam geçişinde gözden geçirilmiş kariyer planlarına ihtiyaç duymaktadırlar (Osipow, 1999). Bu bağlamda bireylerin gelişimlerinin her döneminde güncelliğini hiç yitirmeyen bir kavram olarak karşımıza çıkan mesleki kararsızlığı (Gönültaş, 2021), meslek seçimi sürecinde ciddi kararların eşiğinde olan lise öğrencileri için ele almak oldukça yerinde bir araştırma konusu olacaktır.

Mesleki kararsızlık, seçim yapma yetersizliği olarak tanımlanabilir (Guay, Senécal, Gauthier ve Fernet, 2003). Benzer şekilde Chartrand ve Robbins (1990) da mesleki kararsızlığı, bir meslek seçme ya da kariyer planı uygulama eylemini engelleyen belirsizlik durumu şeklinde açıklamıştır. Ayrıca Tokar, Withrow, Hall ve Moradi (2003) mesleki kararsızlığı, bir mesleği seçme ve bir mesleğe karar verme yeteneğinin eksikliği olarak ifade etmiştir. Bireylerin içinde bulundukları mesleki kararsızlık durumlarını belirlemeye yönelik çalışmalar yapan Dysinger (1950), gelişimsel ve kronik mesleki kararsızlık arasında önemli farklar olduğunu vurgulamıştır. Dysinger'a göre gelişimsel mesleki kararsızlık, eski sınırlı deneyim ve bilgi nedeniyle ortaya çıkan kararsızlık durumudur. Kronik mesleki kararsızlık ise sürekli olarak kariyer kararı verememe şeklinde açıklamaktadır. Gelişimsel kararsızlığı olanlar, bir meslek kararı vermek için sadece iş dünyası hakkında bilgiye ihtiyaç duyarken; kronik kararsızlığ ${ }_{1}$ olanlar, bilgiye sahip olsalar da seçimleri konusunda sürekli olarak endişe duymaya devam ederler. Bu bağlamda gelişimsel mesleki kararsızlığın beklenen ve sağlıklı bir durum olduğunu; ancak kronik kararsızlığın ise istenmeyen bir durum olduğu söylenebilir. Benzer bir bakış açısıyla Savickas (1994) da düzey yaklaşımı fikri ile bireylerde üç farklı mesleki kararsızlık seviyesinin olduğunu ileri sürmüştür. En yüksek seviye, meslek seçimi yapmakla ilgili ciddi kararsızlık ve aşırı endişe olarak; orta seviye ise orta derecede kararsızlık ve kaygı ile tanımlanmaktadır. Son olarak, en düşük seviye ise az seviyede kararsızlık ve az kaygıyı temsil etmektedir. Savickas (1989), en düşük ve orta seviyelerin gelişimsel olarak uygun düzeyde mesleki kararsızlığı temsil ettiğini; en yüksek seviyenin ise kronik kararsızlığı temsil ettiğini belirtmiştir. Buradaki ayrım, kararsız öğrencilerin hepsinin aynı şekilde değerlendirilmesinin yanlış olduğudur. Buradan hareketle bu çalışmanın amaçlarından biri de lise öğrencilerinin mesleki kararsızlık düzeylerini gelişimsel olarak istenilen seviyede tutabilmelerine yardımcı olmaktır.

Yukarıda belirtilen mesleki kararsızlık kavramsallaştırmalarının dışında, Cochran (1992, 1994) gibi bazı araştırmacılar, meslek seçimine yönelik kararsızlığın, öğrencilerin kariyer amaçlarının süreç içerisinde değişmesinden dolayı ortaya çıktığını belirtmişlerdir. Cochran'ın (1997) anlatı yaklaşımına göre meslek seçimi kararsızlığ 1 yaşayan bireyler, meslek seçimi konusunda fazlaca kafa yorup, yeni kararlar almaya başlarlar. Bireyler daha sonra bu yeni kararlarını takip ederek, eski kararlarını değiştirdikleri bilişsel bir sürecin içerisine girerek mesleki kararsızlık yaşayabilirler 
(McInnes ve Chen, 2011). Bu bağlamda bireylerin mesleki kararsızlık yaşamalarında bilişsel süreçlerinin oldukça önemli bir paya sahip olduğu söylenebilir. Lise öğrencileri, gelişim dönemleri itibariyle yaşamda anlam arayışını yoğun bir şekilde yaşamakta, kendilerini değerli ve işe yarar bireyler olarak var etme amacındadırlar (Kılınç ve Uzun, 2020a). Buradan hareketle lise öğrencilerinin, meslek seçimi için önemli adımlar attıkları bu kritik dönemde sağlıklı bir bilişsel süreç yaşamaları için dış desteğe (mesleki grup rehberliği, psikoeğitim, bireysel kariyer danışmanlığı vb.) ihtiyaç duymaları kaçınılmazdır.

Son zamanlarda azımsanmayacak kadar çok sayıdaki araştırmacı, meslek seçimi konusundaki kararsızlığı olumsuz bir durum olarak tanımlamayı reddetmiştir. Örneğin, genel kabul görmüş düşüncenin aksine kararsızlığın bilgeliğini ifade eden Krumboltz (1992), kararsızlığın her zaman zararlı olmadığını, bireyleri meslek seçmeye yönelik motive ettiğini ve arzu edilen bir durum olduğunu belirtmiştir. Benzer şekilde Osipow (1999) da mesleki kararsızlığı, meslek seçeneklerinin değerlendirildiği, karar verildiği, uygulandığı ve yeni kararsızlıklarla sonuçlandığını; bundan dolayı da başka bir karar alma ihtiyacına yol açan normal bir gelişim süreci olduğunu ifade etmiştir. Bu düşüncelerden yola çıkarak Mitchell, Al Levin ve Krumboltz (1999), planlı mutluluk olarak adlandırdıkları bir mesleki karar verme tarzı önermiş ve bireylerin planlanmamış olaylara negatif bir oluşum olarak bakmamalarını, bunun yerine onları büyüme ve öğrenme fırsatları olarak değerlendirmeleri gerektiğini ileri sürmüşlerdir. Lise öğrencilerinin bu yönde olgun değerlendirmeler yapabilecekleri bir bilinci, yaşam serüvenlerinin erken dönemlerinde kazanmaları, yaşamlarının her alanında olduğu gibi sağlıklı bir kariyer gelişimi yaşamaları açısından da oldukça önemlidir.

\section{Lise Öğrencilerinde Kariyer Gelişim Süreci}

Mesleki karar verme süreci hem ergen hem de yetişkin bireylerin yaşam serüvenlerinde önemli bir gelişim görevidir (Sampson, Peterson, Lenz, Reardon ve Saunders, 1996). Mesleki karar verme aşamaları tüm insanlar için farklılıklar göstermekle birlikte genellikle ergenlik döneminde yoğun şekilde gündeme gelir (Akkoç, 2012a; Akkoç, 2012b). Bu bağlamda ergenlik dönemindeki lise öğrencileri, kendilerine en uygun mesleği seçebilmek için ön hazırlık yaparlar (Kılıççı, 2006). Ginzberg, Ginsburg, Axelrad ve Herma (1951) tarafından geliştirilen mesleki gelişim kuramında bu dönem "deneme dönemi" olarak adlandırılır. Deneme dönemi (11-17 yaş), bir geçiş sürecidir. $\mathrm{Bu}$ süreçte ilgiler, yetenekler fark edilir, değerler kazanılır ve zaman algısı gelişmeye başlar. Hoşlanılan ve hoşlanılmayan şeylerle ilgili kesin tanımlar yapılır. Bireyler mesleki hedefleriyle ilgili becerilerinin farkına varmaya başlar. Farklı mesleklerin farklı yaşam biçimleri sağladı̆̆ edilir. Mesleki seçimin getireceği sorumlulukların farkına varılmaya başlanır (Siyez, 2013). Ergenlik dönemindeki meslek seçimi süreçleri üzerine çalışmalar yapan bir diğer kuramcı ise Donald Super'dır. Super (1980) yaşam boyu, yaşam alanı yaklaşımında; ergenlerin "keşfetme döneminde" olduklarını ileri sürmüştür. Keşfetme dönemi (14-24 yaş) bireylerin mesleklerin, kendilerinin bir parçası olduğunu anlamalarıyla başlar ve bireyler bugünleri ile gelecekleri arasında bir bağlantı kurarlar. Bu dönem, bireylerin mesleklere ilişkin daha net fikirlerinin olduğu, kariyer alternatifleri arasından seçim yaptıkları, hangi işte çalışacaklarına karar verdikleri ve bir işte çalışmaya başladıkları dönem olarak ifade edilebilir (Siyez, 2013). Kariyer gelişim kuramları incelendiğinde görülmektedir ki lise öğrencileri; kendilerini ve meslekleri tanıdıkları, sorumluluk almaya başladıkları kritik bir kariyer gelişim sürecinden geçmektedirler. Türkiye'de genel olarak 14-18 yaş aralığındaki bireyler lisede öğrenim görmektedir ve bu dönemde meslekler hakkında bilgi toplayıp geleceğe ilişkin kararını oluştururken, buna bağlı olarak hangi branş ve derslerin kendisine uygun olacağını, hangi yüksek öğretim programına devam etmesi gerektiğini 
belirlemeye çalışmaktadır (Akkoç, 2012b). Diğer yandan lise döneminde bulunan ergenlerin kendilerinden beklenen mesleki gelişim görevlerini başarı ile yerine getirememeleri, onların geleceğe yönelik doğru ve akılcı kararlar vermesini zorlaştırmaktadır (Kırdök, 2010). Maalesef ergenlik döneminde verilen kararların çoğu çevrenin beklentileri ya da akran grubunun kaygılarına yönelik baskılarla gerçekçilikten uzak bir şekilde alınır (Kılınç ve Uzun, 2020b; Noeth, Engen ve Noeth, 1984). Buradan hareketle ergenlik döneminin içinde yer alan lise öğrenimi sürecinin, bireylerin sağlıklı bir kariyer gelişimi yaşamaları için kritik bir dönem olduğu söylenebilir. Genç ve tecrübesiz oldukları bu dönemde, lise öğrencilerinin dış desteğe ihtiyaç duymaları kaçınılmazdır.

\section{Araştırmanın Önemi ve Amacı}

Tüm bu açıklamalardan yola çıkarak mesleki kararsızlık kavramının, meslek seçimi ve iş bulma süreçlerinin her geçen gün zorlaştığı günümüzde de önemini koruduğu söylenebilir (Gönültaş ve Çakır, 2020). Millî Eğitim Bakanlı̆̆ı Ortaöğretim Kurumları Yönetmeliğinde yapılan değişiklik nedeniyle Anadolu lisesi öğrencileri tarafından eskiden dokuzuncu sınıfın sonunda yapılan alan/dal seçimleri; artık seçmeli/ağırlıklı ders seçimi adı altında onuncu sınıfta yapılmaktadır (MEB, 2013). Yönetmelikteki bu değişiklikten önce akademisyenler, çoğunlukla alan/dal seçimi sürecinde olan dokuzuncu sınıf öğrencileri için mesleki grup rehberlik programları geliştirmişlerdir (Aydın, 2007; Çakır, 2003; Karataş ve Yavuzer, 2009; Kırdök, 2010). Yönetmelikte meydana gelen bu değişiklikle beraber, on birinci ve on ikinci sınıfta görecekleri ağırlıklı derslerin seçimini yapacak olan onuncu sınıf öğrencilerine yönelik hazırlanmış ve etkililiği sınanmış mesleki grup rehberliği programı sayısı oldukça azdır (Karaçay, 2021; Şeker ve Kaya, 2019). Bu açıdan, bu çalışmada Çakır (2003) tarafından dokuzuncu sınıf öğrencileri için geliştirilmiş olan mesleki grup rehberlik programının; onuncu sınıf öğrencilerinin mesleki kararsızlık düzeyleri üzerindeki etkililiğinin incelenmesi amaçlanmıştır. Ayrıca kırk beş gün sonra yapılacak olan izlem çalışmasında, bu programın onuncu sınıf öğrencileri üzerindeki etkisinin devam edip etmediği incelenecektir.

Araştırmanın temel amaçlarından yola çıkarak oluşturulan araştırma soruları şöyledir;

1. Mesleki grup rehberliği programına katılan deney grubu öğrencilerinin mesleki kararsızlık düzeyi puanları, hiçbir müdahalenin yapılmadığı kontrol grubunda yer alan öğrencilere göre ne düzeydedir?

2. Uygulanan mesleki grup rehberlik programı, kırk beş gün sonra yapılacak izlem çalışmasında da deney grubundaki öğrenciler üzerindeki etkisini sürdürmekte midir?

\section{YÖNTEM}

\section{Araştırma Deseni}

Bu araştırma, Çakır (2003) tarafından hazırlanan mesleki grup rehberliği programının onuncu sınıf öğrencilerinin mesleki kararsızlık düzeyleri üzerindeki etkisinin sınanmasını amaçlayan ön-test, son-test ve izlem testlerinden oluşan ve karışık desenin kullanıldı̆̆ı yarı deneysel bir çalışmadır. $\mathrm{Bu}$ araştırmada deneklerin seçilme yöntemi olarak eşleştirme (denekleri eşleştirme) kullanılmıştır. Eşleştirme, denek gruplarının denk olma olasılığını artırmak amacıyla kullanılır. Bunun için ilk olarak önceki ilgili araştırmaların sonuçları, kuramlar, araştırmacı deneyimleri ya da uzman görüşleri temel alınarak kararlaştırılan belli değişkenler üzerinde denek çiftleri oluşturulur. Bu araştırmada olduğu gibi denek çiftlerinin oluşturulmasında ön-test puanları da 
kullanılabilmektedir. Daha sonra bu çiftlerdeki denekler seçkisiz bir şekilde deney ve kontrol gruplarına yerleştirilir. Bu şekilde, son-testte ortaya çıkan puan farkının sadece deneysel işlemden kaynaklandığı iddia edilebilir (Büyüköztürk, Kılıç-Çakmak, Akgün, Karadeniz ve Demirel, 2016).

\section{Çalışma Grubu}

Bu araştırmanın çalışma grubunu 2019-2020 eğitim ve öğretim yılında Muğla ilinin Bodrum ilçesindeki Halil İbrahim İper \& Adnan İper Anadolu Lisesinin onuncu sınıfında öğrenim görmekte olan öğrenciler oluşturmuştur. Araştırmada çalışma gruplarını oluşturmak için öncelikle onuncu sınıfta öğrenim gören yüz otuz altı öğrenciye Mesleki Karar Envanteri uygulanmıştır. Deney ve kontrol guruplarında yer alan öğrencilerin, benzer mesleki kararsızlık düzeylerine sahip olmaları amacıyla; Mesleki Karar Envanterinden aldıkları puanlara göre sıralama işlemi yapılmış ve mesleki kararsızlık düzeyi ortalamanın üzerinde olan öğrencilerden en yüksek puanları alan kırk öğrenci belirlenmiştir. Daha sonra bu öğrencilerden mesleki kararsızlık puan ortalamaları birbirine çok yakın olan 20'şer kişilik iki grup oluşturulmuştur. Bu gruplar eşleştirme yöntemiyle deney ve kontrol gruplarına ayrılmıştır. Eşleştirme yöntemi, dişsal değişkenlere (cinsiyet, ön-test puanı vb.) göre deneklerin eşleştirilmesi ve iki gruba ayrılmasıdır. Bu durumda gruplar arasındaki farkların sadece deneysel işlemden kaynaklandığı ileri sürülebilir (Büyüköztürk vd., 2016).

\section{Veri Toplama Araci}

\section{Mesleki Karar Envanteri}

Lise öğrencilerinin mesleki kararsızlık düzeylerinin ölçülmesi amacıyla Çakır (2004) tarafından geliştirilmiştir. Envanter toplam da 30 maddeden oluşmaktadır ve 5'li Likert tipindedir. Envanterden alınabilecek en düşük puan 30, en yüksek puan ise 150'dir. Envanterden alınabilecek en yüksek puan, öğrencinin mesleki kararsızlığının yüksek düzeyde olduğunu; en düşük puan ise öğrencideki mesleki kararsızlığın düşük düzeyde olduğunu göstermektedir. Mesleki Karar Envanterinin içsel çatışmalar (8 madde), kendini yeterince tanımama (7 madde), meslek ve alan bilgisi eksikliği (7 madde), meslek seçimine ilişkin akılcı olmayan inançlar (4 madde) ve dişsal çatışmalar (4 madde) olmak üzere beş alt boyutu bulunmaktadır. Envanterden, toplam mesleki kararsızlık düzeyi puanı alınabilmektedir. Envanter toplam varyansın \%40.53'ünü açıklamaktadır. Mesleki Karar Envanterinin genel iç tutarlık katsayısı .85' dir (Çakır, 2004). Bu çalışma kapsamında ise Cronbach alfa iç tutarlık katsayısı envanterin tamamında .95 olarak bulunmuştur.

\section{İşlem}

Öncelikle çalışmanın yapılabilmesi için gerekli resmi izinler alınmıştır. Daha sonra öğrencilerin öntest puanları dikkate alınarak eşleştirme yöntemi ile deney ve kontrol grupları oluşturulmuştur. Deney grubuyla yapılan uygulamalar Halil İbrahim İper \& Adnan İper Anadolu Lisesinde fizikî açıdan uygun olan bir sınıfta yürütülmüştür. Kontrol grubuna ise bu süreç boyunca herhangi bir müdahale yapılmamıştır. İlk oturumda, deney grubundaki öğrencilere mesleki grup rehberliği programının amaçları ve içeriği hakkında bilgi verilmiştir. Araştırmacılar tarafından yürütülen mesleki grup rehberliği programı, her hafta sadece bir oturum yapılarak toplamda on oturumda tamamlanmıştır. Oturumların süreci kırk ila elli dakika arasındadır. On haftalık mesleki grup rehberliği programı uygulamasından sonra hem deney hem de kontrol grubuna aynı zaman dilimi içerisinde son-test uygulanmıştır. Ayrıca son-test uygulamasından kırk beş gün sonra hem deney hem de kontrol grubuna izlem testi uygulanması yapılmıştır. Uygulanan oturumların temel amaçları ve kazanımları Tablo-1'de özetlenmiştir. 
Tablo-1. Mesleki Grup Rehberliği Programı

\begin{tabular}{cl}
\hline $\begin{array}{c}\text { Oturum } \\
\text { Sayısı }\end{array}$ & \multicolumn{1}{c}{ Amaç ve Kazanım } \\
\hline & Öğrencilerin, mesleki grup rehberliğinin genel amacını kavrayabilmesi; uygulanan mesleki \\
1. & $\begin{array}{l}\text { grup rehberliği programında uyulması gereken kuralları bilmesi; verilecek ev ödevlerinin } \\
\text { önemini kavrayabilmesi; grup oturumları dışında düzenlenecek etkinliklere katılımın önemini } \\
\text { kavrayabilmesi; birbirlerini tanımanın ve saygılı olmanın önemini bilmesi. }\end{array}$
\end{tabular}

Öğrencilerin, on birinci sınıfta ağırlıklı ders seçimi ve meslek seçimi ile ilgili kavramları

2. bilmesi; ağırlıklı ders ve meslek seçiminde göz önünde bulundurulması gereken faktörlerin farkında olması; iş, meslek, meslek alanı ve on birinci sınıfta öğrenim görülecek olan ağırlıklı dersler hakkında bilgi sahibi olması.

Öğrencilerin, meslek seçiminde göz önünde bulundurulması gereken etmenlerin farkında olması; kendimizi (yetenek, ilgi, mesleki değerler ve diğer kişilik özelliklerini) ve çevremizdeki

3. imkânları (meslek alanlarını, seçmeli dersleri, meslekleri, yükseköğretim programlarını) tanımak için kimlere, nerelere başvurabileceğini bilmesi.

Öğrencilerin, psikolojik (yetenek, ilgi, mesleki değer, kişilik özellikleri vb.), kişisel ve sosyal (yaş, cinsiyet, sosyoekonomik düzey) özellikleri hakkında bilgi verilen bir kişinin bu

4. özelliklerine uygun meslekler önerebilmesi; meslek seçerken o mesleğin hangi özelliklerine dikkat edilmesi gerektiğini bilmesi; meslekler hakkında bilgi edinmenin önemini kavraması.

Öğrencilerin, meslekler hakkında bilgi edinmesi; her bir mesleğin farklı bir takım kişilik

5. özellikleri (yetenek, ilgi, mesleki değer gibi) gerektirdiğinin farkında olması; üniversite yükseköğretim programları ve meslekler hakkında bilgi veren yayınları tanıması.

Öğrencilerin, psikolojik (yetenek, ilgi, mesleki değer, kişilik özellikleri vb.), kişisel ve sosyal (yaş, cinsiyet, sosyoekonomik düzey) özellikleri hakkında bilgi verilen bir kişiye bu

6. özelliklerine uygun meslekler önerebilmesi; meslekler (lise öğreniminde Türkçe-Matematik ağırlıklı dersler seçen bireylerin girebileceği yükseköğretim programları ve meslekler) hakkında bilgi sahibi olması.

Öğrencilerin, çelişkili ders ve meslek seçimi yapan kişilerin mesleki yaşam öykülerindeki çelişkileri bularak bu vaka ile kendi durumları arasında ilişki kurabilmesi; meslekler (lise öğreniminde sosyal bilimler ağırlıklı ders seçen bireylerin girebileceği yükseköğretim programları ve meslekler) hakkında bilgi sahibi olması.

Öğrencilerin, meslekler (lise öğreniminde fen bilimleri ağılıklı ders seçen bireylerin girebileceği yükseköğretim programları ve meslekler) hakkında bilgi sahibi olması; amaç

8. belirlemenin insan yaşamındaki ve meslek seçimindeki önemini bilmesi; öğrencilerin kendilerine, ilgi, yetenek ve mesleki değer yargılarına uygun mesleki bir amaç belirleyebilmesi.

Öğrencilerin, bilgi işleme yaklaşımının kuramsal görüşleri hakkında bilgi sahibi olması; bilgi

9. işleme yaklaşımına göre problem çözme basamakları hakkında bilgi sahibi olması; bilgi işleme yaklaşımına göre meslek seçimi hakkında bilgi sahibi olması.

10.

Mesleki grup rehberliği programına katılan üyelerin uygulamaya ilişkin düşüncelerini ve yaşantılarını paylaşması; programa katılanların oturumlardan kazandıklarını tartışması.

\section{Verilerin Analizi}

Araştırma sürecinin yürütülmesi amacıyla oluşturulan deney ve kontrol gruplarında yer alan öğrencilerin, Mesleki Karar Envanterinden aldıkları ön-test, son-test ve izlem ölçümü puanları; 
araştırmanın cevap aradığı soruları yanıtlayabilecek şekilde bilgisayar ortamına aktarılmıştır. Bilgisayar ortamına aktarılan verilerin, yapılacak olan analizler için gerekli olan parametrik özellikleri karşılayıp karşılamadığı test edilmiştir. Bu amaçla verilerin normal dağılım sayıltısını karşılayıp karşılamadığına dair basıklık ve çarpıklık katsayılarına bakılmıştır. Verilerin basıklık ve çarpıklık katsayılarının referans değer aralığı olan -1.00 ila +1.00 aralığında (Çokluk, Şekercioğlu ve Büyüköztürk, 2014) yer almadığ1 görülmüştür. Ayrıca Kolmogrov Simirnov Normallik Testinde de verilerin normal dağılmadığı tespit edilmiştir. Bu sonuçlardan dolayı verilerin analiz işlemlerinde non-parametrik istatistik teknikleri kullanılmıştır. Deney ve kontrol grubunun mesleki kararsızlık son-test puanlarının ön-test puanlarına göre anlamlı bir şekilde azalıp azalmadığını belirlemek için non-parametrik Wilcoxon İşaretli Sıralar Testi yapılmıştır (Büyüköztürk, 2014). Uygulamalar sonrasında deney ve kontrol gruplarından elde edilen mesleki kararsızlık ön-test, son-test ve izlem ölçümleri puanlarının birbirlerinden anlamlı bir şekilde farklılaşıp farklılaşmadığının test edilmesi amacıyla ise non-parametrik Mann Whitney U-testi tekniği kullanılmıştır (Büyüköztürk, 2014). İstatistik analizlerde SPSS 20.0 programı kullanılmış, anlamlılık düzeyi olarak .05 alınmıştır.

\section{BULGULAR}

Mesleki grup rehberliği programının, deney grubundaki öğrencilerin mesleki kararsızlık düzeyleri üzerinde etkili olup olmadığının incelenmesine başlanmadan önce deney ve kontrol grubu katılımcılarının Mesleki Karar Envanteri ön-testinden almış oldukları puanların anlamlı bir şekilde farklılaşıp farklılaşmadığını belirlemek üzere non-parametrik Mann Whitney U-testi yapılmıştır ve ulaşılan bulgular Tablo-2' de verilmiştir.

Tablo-2. Deney ve Kontrol Grubunun Mesleki Karar Envanteri Ön-test Puanlarına göre Mann Whitney U-testi Sonucu

\begin{tabular}{lccccc}
\hline Grup & $\mathrm{n}$ & $\begin{array}{c}\text { Sira } \\
\text { Ortalamas }\end{array}$ & $\begin{array}{c}\text { Sira } \\
\text { Toplam }\end{array}$ & $\mathrm{U}$ & $\mathrm{p}$ \\
\hline Deney & 20 & 20.78 & 415.50 & & \\
Kontrol & 20 & 20.23 & 404.50 & 194.50 & .88 \\
\hline
\end{tabular}

Tablo-2 incelendiğinde, deney ve kontrol grubunun Mesleki Karar Envanterinden aldıkları ön-test puanları üzerinde yapılan Mann Whitney-U testi sonucunda, gruplar arasındaki fark istatistiksel olarak anlamlı değildir ( $\mathrm{U}=194.50, \mathrm{p}>.05$ ). Başka bir deyişle, yapılacak olan uygulama öncesinde deney ve kontrol grubundaki öğrencilerin mesleki kararsılılk düzeyleri birbirine eşittir. $\mathrm{Bu}$ bağlamda deney ve kontrol gruplarına üye seçilirken yapılan eşleştirme işleminin amaca hizmet ettiği söylenilebilir.

Araştırmanın birinci sorusuna cevap bulmak amacıyla ilk olarak öğrencilerin ön-test, son-test ve izlem ölçümlerinden almış oldukları puanlara ilişkin aritmetik ortalama ve standart sapma verileri Tablo-3'te sunulmuştur. 
Tablo-3. Deney ve Kontrol Gruplarının Mesleki Kararsızlık Düzeyi Puanlarına İlişkin Ön-test, Son-test ve İzlem Ölçümlerinin Karşılaştırması

\begin{tabular}{lllcc}
\hline Grup & \multicolumn{1}{c}{ Ön-Son-İzlem Ölçümleri } & $\mathrm{N}$ & $\mathrm{X}$ & $\mathrm{SS}$ \\
\hline \multirow{3}{*}{ Deney } & Ön-Test & 20 & 93.85 & 14.93 \\
& Son-Test & 20 & 58.05 & 17.09 \\
& İzleme Testi & 20 & 56.48 & 18.21 \\
\cline { 2 - 5 } Kontrol & Ön-Test & 20 & 91.95 & 13.97 \\
& Son-Test & 20 & 90.90 & 9.45 \\
& İzleme Testi & 20 & 89.68 & 12.44 \\
\hline
\end{tabular}

Tablo-3'de mesleki kararsızlık düzeyini azaltmaya yönelik yapılan mesleki grup rehberliği programının uygulandığı deney grubu öğrencilerinin; mesleki kararsızlık düzeyi puanları, mesleki grup rehberliği programı uygulaması öncesi ön-test puan ortalaması 93.85 iken, bu puan uygulama sonrasinda 58.05'e düşmüş ve kırk beş gün sonra yapılan izlem testi sonrasında ise 56.48 puanda kalarak kalıcılığını kanıtlamıştır. Mesleki kararsızlık düzeyini düşürmeye yönelik yapılan mesleki grup rehberliği programı uygulamasına katılmayan kontrol grubunun ön-testten aldığ1 ortalama puan 91.95 iken, bu puan son-testte 90.90 ve kırk beş gün sonra yapılan izlem testi sonrasında ise 89.68 olmuştur. Bu bağlamda, mesleki kararsızlık düzeyini düşürmek amacıyla uygulanan mesleki grup rehberliği programına katılan öğrencilerin, mesleki kararsızlık düzeylerinde bir azalma olduğu söylenebilir.

Mesleki kararsızlık düzeyini düşürmeye yönelik yapılan grup rehberliği oturumlarına katılan deney grubu öğrencileri ile oturumlara katılmayan kontrol grubu öğrencilerinin; deney öncesi, deney sonrası ve izlem ölçümlerinde Mesleki Karar Envanterinden aldıkları puanların karşılaştırılmasına ilişkin sonuçlar Şekil-1'de verilmiştir.

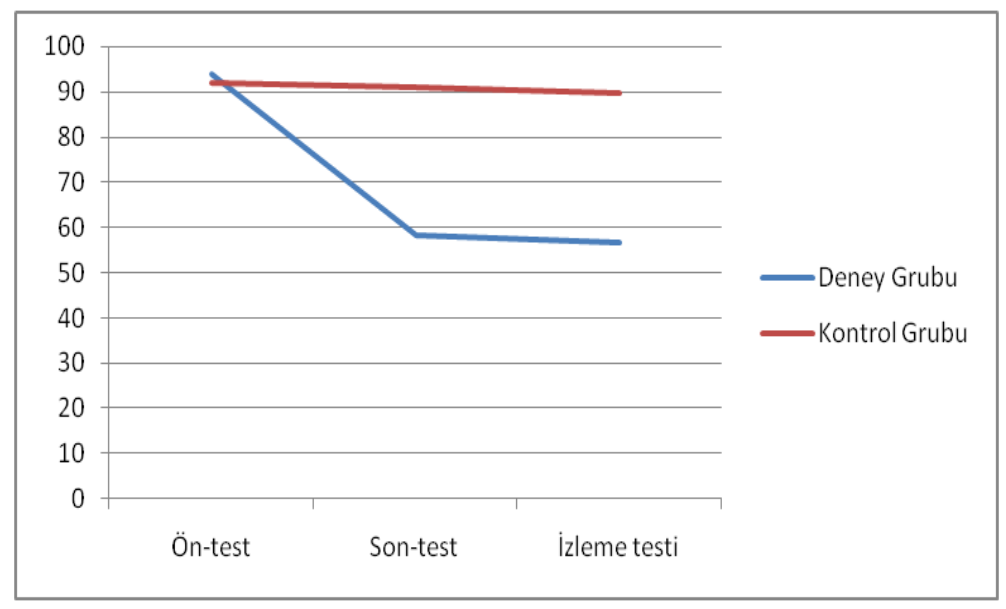

Şekil-1. Öğrencilerin Mesleki Karar Düzeyi Puanlarının Karşılaştırılması

Şekil-1 incelendiğinde, mesleki grup rehberliği oturumlarına katılan deney grubu öğrencilerinin mesleki kararsızlık puanlarının düştüğü; ancak mesleki grup rehberliği oturumlarına katılmayan kontrol grubu öğrencilerinin ise mesleki karasızlıklarında kayda değer bir değişimin olmadığı görülmektedir. Ulaşılan bu sonuçların istatistiksel olarak anlamlı olup olmadığının belirlenmesi için aşağıda verilen bazı non-parametrik analizlere başvurulmuştur. 
Deney ve kontrol grubunda yer alan öğrencilerin, mesleki kararsızlık düzeyi son-test puanlarının ön-test puanlarına göre anlamlı bir şekilde azalıp azalmadığını belirlemek için non-parametrik Wilcoxon İşaretli Sıralar Testi yapılmış ve buna ilişkin sonuçlar Tablo-4'te verilmiştir.

Tablo-4. Deney ve Kontrol Gruplarının Mesleki Karar Envanteri Ön-test ve Son-test Puanlarına Göre Wilcoxon İşaretli Sıralar Testi Sonuçları

\begin{tabular}{llccccc}
\hline Grup & Son-test / Ön-test & $\mathrm{n}$ & Sira Ortalaması & $\begin{array}{c}\text { Sira } \\
\text { Toplam }\end{array}$ & $\mathrm{z}$ & $\mathrm{p}$ \\
\hline \multirow{2}{*}{$\begin{array}{l}\text { Deney } \\
\text { Grubu }\end{array}$} & Negatif Sıra & 20 & 10.50 & 210.00 & & \\
& Pozitif Sıra & 0 & .00 & .00 & -3.921 & $.00^{*}$ \\
& Eşit & 0 & - & - & & \\
\hline \multirow{2}{*}{ Kontrol } & Negatif Sıra & 14 & 8.61 & 120.50 & & \\
Grubu & Pozitif Sıra & 6 & 14.92 & 89.50 & -.579 & .56 \\
& Eşit & 0 & - & - & & \\
\hline${ }^{*} \mathrm{p}<.05$ & & & & &
\end{tabular}

Tablo-4'te deney ve kontrol grubu öğrencilerinin, deney öncesi ve sonrası mesleki kararsızlık düzeylerinin anlamlı bir farklılık gösterip göstermediğine ilişkin Wilcoxon İşaretli Sıralar Testi sonuçları görülmektedir. Analiz sonuçları incelendiğinde, mesleki grup rehberliği etkinliklerine katılmayan kontrol grubu öğrencilerinin, Mesleki Karar Envanterinden aldıkları deney öncesi ve sonrası puanlar arasında anlamlı bir farkın olmadığı anlaşılmaktadır ( $\mathrm{z}=-$.597, p>.05). Ancak Tablo4'te mesleki grup rehberliği etkinliklerine katılan deney grubu öğrencilerinin, Mesleki Karar Envanterinden aldıkları deney öncesi ve sonrası puanlar arasında anlamlı bir farkın olduğu görülmektedir ( $\mathrm{z}=-3.921, \mathrm{p}<.05)$. Fark puanlarının sıra ortalaması ve toplamları dikkate alındığında gözlenen bu farkın, negatif sıralar yani son-test lehinde olduğu anlaşılmaktadır.

Deney ve kontrol grubunda yer alan öğrencilerin, Mesleki Karar Envanteri son-testlerinden almış oldukları puanların anlamlı bir şekilde farklılaşıp farklılaşmadığını belirlemek üzere yapılan nonparametrik Mann Whitney U-testi sonucuna ilişkin bulgular Tablo-5'te verilmiştir.

Tablo-5. Deney ve Kontrol Gruplarının Mesleki Karar Envanteri Son-test Puanlarına göre Mann Whitney U-testi Sonucu

\begin{tabular}{lccccc}
\hline \multicolumn{1}{c}{ Grup } & $\mathrm{n}$ & $\begin{array}{c}\text { Sira } \\
\text { Ortalamas }\end{array}$ & $\begin{array}{c}\text { Sira } \\
\text { Toplam }\end{array}$ & $\mathrm{U}$ & $\mathrm{p}$ \\
\hline Deney & 20 & 11.28 & 225.50 & & 15.50 \\
Kontrol & 20 & 29.73 & 594.50 & & $.00^{*}$ \\
\hline
\end{tabular}

${ }^{*} \mathrm{p}<.05$

Mesleki grup rehberliği programına katılanlar ile böyle bir programa katılmayan öğrencilerin uygulama sonrası Mesleki Karar Envanterinden aldıkları puanların Mann Whitney U-testi sonuçları Tablo-5'te verilmiştir. Tablo-5 incelendiğinde, on haftalık deneysel çalışma sonucunda, mesleki grup rehberliği programına katılan onuncu sınıf öğrencileri ile böyle bir programa katılmayan onuncu sınıf öğrencilerinin mesleki kararsızlık düzeyleri arasında anlamlı bir fark olduğu görülmektedir ( $U=15.50, \mathrm{p}<.05)$. 
Deney ve kontrol gruplarında yer alan öğrencilerin, uygulamalardan kırk beş gün sonra Mesleki Karar Envanteri izlem testinden almış oldukları puanların anlamlı bir şekilde farklılaşıp farklılaşmadığını belirlemek ve araştırmanın ikinci sorusuna cevap bulmak için non-parametrik Mann Whitney U-testi yapılmıştır. Ulaşılan bulgular Tablo-6'da sunulmuştur.

Tablo-6. Deney ve Kontrol Gruplarının Mesleki Karar Envanteri İzlem Testi Puanlarına Göre Mann Whitney U-testi Sonucu

\begin{tabular}{lccccc}
\hline \multicolumn{1}{c}{ Grup } & $\mathrm{n}$ & $\begin{array}{c}\text { Sira } \\
\text { Ortalamas }\end{array}$ & $\begin{array}{c}\text { Sira } \\
\text { Toplam }\end{array}$ & $\mathrm{U}$ & $\mathrm{p}$ \\
\hline Deney & 20 & 11.14 & 222.80 & & \\
Kontrol & 20 & 29.34 & 586.80 & 14.95 & $.00^{*}$ \\
\hline
\end{tabular}

${ }^{*} \mathrm{p}<.05$

Tablo-6'ya göre deney ve kontrol grubundaki öğrencilerin Mesleki Karar Envanterinden aldıkları izlem testi puanlarıyla yapılan Mann Whitney U-testi sonucunda, gruplar arasındaki fark istatistiksel olarak anlamlı bulunmuştur $(\mathrm{U}=14.95, \mathrm{p}<.05)$. Bu bağlamda mesleki grup rehberliği oturumlarına katılan deney grubu öğrencilerinin, bu oturumlara katılmayan kontrol grubu öğrencilerine göre mesleki kararsızlık puanları arasındaki farklılığın kırk beş gün sonrasında da kalıcılığını koruduğu söylenebilir.

\section{TARTIŞMA, SONUÇ ve ÖNERİLER}

$\mathrm{Bu}$ araştırmada uygulanan mesleki grup rehberliği programının amacı, lise öğrencilerinin mesleki kararsızlık düzeylerini azaltmaya çalışmak ve onların mesleki karar düzeylerini artırmaktır. Bu çerçevede doğrultusunda Çakır (2003) tarafından daha önceden dokuzuncu sınıf öğrencilerine yönelik geliştirilen mesleki grup rehberliği programının, onuncu sınıf öğrencilerinin mesleki kararsızlık düzeyleri üzerinde de etkili olup olmadığı sınanmıştır. Belirtilen temel amaç doğrultusunda deney grubundaki öğrencilere on oturumluk mesleki grup rehberliği programı uygulanmıştır. Kontrol grubundaki öğrencilere ise herhangi bir müdahale yapılmamıştır. On hafta süreyle yürütülen mesleki grup rehberliği programının sonunda, her iki gruptaki öğrencilere sontest çalışması olarak, ön-test çalışmasında olduğu gibi Mesleki Karar Envanteri uygulanmıştır. Son-test uygulamasından elde edilen bulgular incelendiğinde, mesleki grup rehberliği programının onuncu sınıf öğrencilerinin mesleki kararsızlık düzeylerini azaltmada etkili olduğu görülmüştür. Ayrıca öğrencilerin mesleki kararsızlık düzeylerindeki bu azalmanın kırk beş gün sonra yapılan izlem testinde de kalıcılığını korunduğu tespit edilmiştir. Elde edilen bu bulgular, Çakır (2003) tarafından dokuzuncu sınıf öğrencilerinin mesleki kararsızlıklarını azaltmak için geliştirilen mesleki grup rehberliği programının onuncu sınıf öğrencileri üzerinde de etkili olduğunu göstermektedir.

$\mathrm{Bu}$ araştırmanın çıkış noktası, eskiden dokuzuncu sınıfın sonunda yapılan alan/dal seçimlerinin artık seçmeli/ağırlıklı ders seçimi adı altında onuncu sınıfta yapılıyor olmasıdır. Buradan hareketle dokuzuncu sınıflar için geliştirilmiş olan mesleki grup rehberliği programlarının onuncu sınıf öğrencileri için de kullanılıp kullanılamayacağı sorunu, ülkemizdeki yerel bir sorun olarak ele alınmıştır. Bu bakımdan eğitim sistemimizde yaşanan bu değişime referans gösterilebilecek, yurt dışı alanyazınından olası bir örnek durum bulmak mümkün olmamaktadır. Buradan hareketle alanyazın taraması, bu sorunun yerel bağlamda desteklenmesi üzerine kurgulanmıştır. Alanyazın incelendiğinde, mesleki ve/veya kariyer kararsızlı̆̆ı üzerinde yapılan çalışmaların; okul öncesi 
(Isaacson ve Brown, 2000), ilkokul (Patton ve McMahon, 2006), ortaokul (Anovunga, John ve Akpadago, 2021), lise (Kırdök ve Boran, 2020) ve üniversite öğrencileri (Lee, Gray ve Kim, 2021; Mutlu, Korkut-Owen, Özdemir ve Ulaş-Kılıç, 2019) ile yetişkin (Varlık ve Apaydın, 2020) çalışma grupları gibi birçok farklı örneklem üzerinde planlandığı anlaşılmıştır. Lise öğrencileri örnekleminde yapılan mesleki ve/veya kariyer kararsızlığı ile ilgili çalışmalar incelendiğinde, bu çalışmaların büyük bir çoğunluğunun ilişkisel tarama modeli ile kurgulandığı anlaşılmıştır (Aydemir, 2017; Baltacı, Öztemel ve Tras, 2020; Jemini-Gashi, Duraku ve Kelmendi, 2019; Şeker, 2021; Yılmaz ve Bedel, 2021). Sınırlı sayıda yapılmış olan deneysel çalışmalar ise bu araştırma sonucunda elde edilen bulguları destekler niteliktedir.

Araştırmanın bulgularını destekleyen çalışmalardan ilki, geliştirmiş olduğu mesleki grup rehberliği programı bu araştırma içerisinde sınanan, Çakır'ın (2003) yaptığı ön-test, son-test modelli kontrol gruplu deneysel çalışmadır. Bu çalışmada, bilgiyi işleme modelinin problem çözme aşamaları temel alınarak geliştirilen, on oturumluk mesleki kararsızlığı azaltmaya yönelik grup rehberliği programının, dokuzuncu sınıf öğrencilerinin mesleki kararsızlık düzeyleri üzerinde ne ölçüde etkili olduğunu incelemiştir. Araştırma sonucunda elde edilen bulgular, uygulanan mesleki grup rehberliği programının dokuzuncu sınıf öğrencilerinin mesleki kararsızlık düzeylerinin azaltılmasında etkili olduğunu açıkça ortaya koymaktadır. Araştırma sonuçlarını destekler nitelikte olan bir diğer çalışma ise Kırdök'ün (2010) yaptığı ön-test, son-test modelli kontrol gruplu olan deneysel çalışmadır. Bu çalışmada, geliştirilmiş olan on oturumluk mesleki karar verme programı dokuzuncu sınıf öğrencileri üzerinde yürütmüştür. Uygulama sonucunda elde edilen bulgular, bilgiyi işleme yaklaşımı temelli mesleki karar verme programının dokuzuncu sınıf öğrencilerinin, mesleki kararsızlık düzeylerini azaltmada etkili olduğunu ortaya çıkarmıştır. Benzer şekilde Karaçay (2021) da geliştirmiş olduğu kariyer karar verme grup rehberliği programının ortaöğretim onuncu sınıf öğrencilerinin kariyer karar verme güçlüklerine etkisini incelemiştir. Bu araştırma, kontrol gruplu ön-test, son-test ve izlem testi deseni ile deneysel bir çalışma olarak planlanmıştır. Araştırmadan elde edilen sonuçlar incelendiğinde, kariyer karar verme grup rehberliği programının onuncu sınıf öğrencilerinin kariyer karar verme güçlükleri toplam puanlarını azalttığı görülmüştür. Araştırmanın bulgularıyla örtüşen bir diğer çalışma ise Doğan ve Bacanlı'nın (2012) kariyer karar verme programının, lise öğrencilerinin karar verme güçlükleri üzerindeki etkisini inceledikleri araştırmadır. Bu araştırmada ön-test, son-test ve izlem testi modelli plesebo kontrol gruplu olan deneysel bir desen kullanılmıştır. Yapılan uygulamalardan sonra deney grubunun tüm kariyer karar verme güçlük seviyeleri, plasebo kontrol grubuna kıyasla önemli ölçüde azalmıştır. Ayrıca deney grubuna ana uygulamadan sonra on bir hafta süreyle kariyer karar verme programı uygulanmış ve kariyer karar verme güçlük düzeylerinde azalmanın devam ettiği anlaşılmıştır. Son olarak Çelik (2020), mesleki grup rehberliği programının göçmen lise öğrencilerinin kariyer karar verme süreçlerine etkisini incelenmek için deneysel bir çalışma yapmıştır. Uygulanan mesleki grup rehberliği programının göçmen lise öğrencilerinin mesleki karar verme düzeylerini artırdığı sonucuna ulaşılmıştır. Bu bağlamda lise öğrencilerinde mesleki kararsızlığın azaltılması konusunda kültürümüzde yapılan grup rehberliği çalışmalarının, birçok sınıf düzeyinde ve farklı yapıdaki örneklemlerde başarılı sonuçlar verdiği söylenebilir.

Mevcut araştırmaya benzer olarak Şeker ve Kaya (2019), daha önceden Kırdök (2010) tarafından dokuzuncu sınıf öğrencileri için geliştirilmiş olan bilgiyi işleme kuramı temelli mesleki karar verme grup rehberliği programını, onuncu sınıf öğrencileri üzerindeki etkililiğini sınamışlardır. Şeker ve Kaya (2019) bu amaçla, onuncu sınıf öğrencileri üzerinde ön-test, son-test modelli kontrol 
gruplu deneysel bir çalışma yürütmüşlerdir. Elde ettikleri bulgular neticesinde, Kırdök (2010) tarafından dokuzuncu sınıf öğrencileri için geliştirilmiş olan mesleki grup rehberliği programının, onuncu sınıf öğrencilerinin de mesleki kararsızlık düzeylerini düşürmede etkili olduğu sonucuna ulaşmışlardır.

Sonuç olarak, lise öğrencilerinin mesleki kararsızlık düzeylerini düşürmek için uygulanan mesleki grup rehberliği programlarının, öğrencilerin mesleki kararsızlık düzeylerini düşürmede önemli bir etkisinin olduğu görülmüştür. Bu bağlamda araştırmanın bulguları doğrultusunda sınanmış olan mesleki grup rehberliği programının, on birinci ve on ikinci sınıfta alacakları seçmeli/ağırlıklı dersleri seçme sürecinde olan onuncu sınıf öğrencilerinin, yaşadıkları karar verme sorunlarının çözümüne katkıda bulunabileceği ifade edilebilir. Ayrıca dokuzuncu ve onuncu sınıf öğrencilerinde test edilen Çakır'ın (2003) mesleki grup rehberliği programının, okul psikolojik danışmanları ve sınıf rehber öğretmenlerince her iki sınıf düzeyinde de kolaylıkla uygulanabilecek bir program olarak işlevsel ve etkili bir kaynak olduğu söylenebilir.

$\mathrm{Bu}$ araştırma, Anadolu lisesinde öğrenim görmekte olan ve araştırmaya katılan onuncu sınıf öğrencileri ile sınırlıdır. Araştırmada kullanılan mesleki grup rehberliği programının, akademik eğitim veren liseler dışında, mesleki ve teknik eğitim veren liselerde de uygulanması ve ayrıca on birinci ve on ikinci sınıf düzeyinde öğrenim gören lise öğrencileri ile de yürütülmesi önerilebilir. Farklı sınıf düzeylerinden ve lise türlerinden elde edilen sonuçların karşılaştırılabilmesi için farklı sınıf düzeyleriyle ve lise türleriyle eş zamanlı yürütülen araştırmalar planlanabilir.

\section{KAYNAKLAR}

Akkoç, F. (2012a). Lise öğrencilerinin mesleki kararsızlıkları ile kariyer inançları arasındaki ilişki. Dokuz Eylül Üniversitesi Buca Ĕ̆itim Fakültesi Dergisi, (32), 49-70.

Akkoç, F. (2012b). Lise öğrencilerinin mesleki kararsızlıklarının bazı sosyo-demografik faktörlere göre incelenmesi. Mehmet Akif Ersoy Üniversitesi Eğitim Fakültesi Dergisi, (23), 215-233.

Anovunga, A. A., John, N. Y., \& Akpadago, J. (2021). Career decision making among young adults in Ghanaian secondary schools using supers career choice theory as a lens. International Journal of Psychology and Counselling, 13(3), 41-51. https://doi.org/10.5897/IJPC2021.0651

Aydemir, L. (2017). Lise öğrencilerinin meslek seçimindeki kararsızlıklarına etki eden faktörler (Trabzon örneği). Siirt Üniversitesi Sosyal Bilimler Enstitüsü Dergisi, 5(10), 651-664.

Aydın, D. (2007). Grup rehberliğinin lise 1. sınıf öğrencilerinin alan tercihlerinde gerçekçi davranmalarına etkisi. Ahi Evran Üniversitesi Kırşehir Eğitim Fakültesi Dergisi, 8(1), 137-155.

Baltacı, U. B., Öztemel, K., \& Tras, Z. (2020). Investigation of the relationship between adolescents' career indecision, and social support perception and basic psychological needs. International Education Studies, 13(10), 113-123. https://doi.org/10.5539/ies.v13n10p113

Büyüköztürk, Ş. (2014). Veri analizi el kitabı (19.Basım). Ankara: Pegem Akademi.

Büyüköztürk, Ş., Kılıç-Çakmak, E., Akgün, Ö. E., Karadeniz, Ş., \& Demirel, F. (2016). Bilimsel araştırma yöntemleri (21.Basım). Ankara: Pegem Akademi.

Chartrand, J. M., \& Robbins, S. B. (1990). Using multidimensional career decision instruments to assess career decidedness and implementation. The Career Development Quarterly, 39(2), 166177.

Cochran, L. (1992). The career project. Journal of Career Development, 18(3), 187-197. https://doi.org/10.1177/089484539201800303

Cochran, L. (1994). What is a career problem?. The Career Development Quarterly, 42(3), 204-215. https://doi.org/10.1002/j.2161-0045.1994.tb00935.x 
Cochran, L. (1997). Career counseling: A narrative approach. Newbury Park, CA: Sage Publications.

Çakır, M. A. (2003). Bir mesleki grup rehberliği programının lise öğrencilerinin mesleki kararsızlık düzeylerine etkisi (Yayımlanmamış doktora tezi). Ankara Üniversitesi, Eğitim Bilimleri Enstitüsü, Ankara.

Çakır, M. A. (2004). Mesleki karar envanterinin geliştirilmesi. Ankara Üniversitesi Ĕ̆itim Bilimleri Fakültesi Dergisi, 37(2), 1-14.

Çelik, M. B. (2020). Bir mesleki grup rehberliği çalışmasının göç ile gelen öğrencilerin gelecek beklentileri ve kariyer karar verme sürecine etkisinin incelenmesi (Yayımlanmamış yüksek lisans tezi). Burdur Mehmet Akif Ersoy Üniversitesi, Eğitim Bilimleri Enstitüsü, Burdur.

Çokluk, Ö., Şekercioğlu, G., \& Büyüköztürk, Ş. (2014). Sosyal bilimler için çok değişkenli istatistik SPSS ve LISREL uygulamaları (3.Basim). Ankara: Pegem Akademi.

Doğan, H., \& Bacanl1, F. (2012). The effect of a career decision-making group guidance program on career decision-making difficulties. Energy Education Science and Technology Part B: Social and Educational Studies, (Special Issue), 912-916.

Dysinger, W. S. (1950). Maturation and vocational guidance. Occupations, (29), 198-201.

Ginzberg, E., Ginsburg, S.W., Axelrad, S., \& Herma, J.L. (1951). Occupational choice: An approach to general theory. New York: Columbia University Press.

Gönültaş, O., \& Çakır, M. A. (2020). Mesleki grup rehberliği programının lise 11. sınıf öğrencilerinin mesleki olgunluk düzeylerine etkisi. Insan ve Sosyal Bilimler Dergisi, 3(2), 639653.

Gönültaş, O. (2021). Lise öğrencilerine yönelik kariyer danışmanlığı ve mesleki rehberlik alanında yapılan deneysel çalışmaların incelenmesi. Academia Eğitim Araştırmaları Dergisi, 6(1), 233244.

Guay, F., Senécal, C., Gauthier, L., \& Fernet, C. (2003). Predicting career indecision: A selfdetermination theory perspective. Journal of Counseling Psychology, 50(2), 165-177. https://doi.org/10.1037/0022-0167.50.2.165

Güneş, A., \& Korkut-Owen, F. (2021). Anadolu lisesi öğrencilerinin mesleki kararsızlıklarının akademik erteleme ve çeşitli değişkenler açısından incelenmesi. Pamukkale Üniversitesi Ĕ̆gitim Fakültesi Dergisi, (51), 499-529. https://doi.org/10.9779/pauefd.705018

Jemini-Gashi, L., Duraku, Z. H., \& Kelmendi, K. (2019). Associations between social support, career self-efficacy, and career indecision among youth. Current Psychology, 1-7. https://doi.org/10.1007/s12144-019-00402-x

Isaacson, L. E., \& Brown, D. (2000). Career information, career counseling, and career development (7.Basım). Needham Heights, MA: Allyn \& Bacon.

Karaçay, G. (2021). Kariyer karar verme grup rehberliği programının kariyer karar verme güçlüklerine ve temel ihtiyaçlara etkisi (Yayımlanmamış yüksek lisans tezi). Hasan Kalyoncu Üniversitesi, Sosyal Bilimler Enstitüsü, Gaziantep.

Karataş, Z., \& Yavuzer, Y. (2009). Yaratıcı drama temelli mesleki grup rehberliğinin lise öğrencilerinin mesleki olgunluk puanlarına etkisi. Eğitim Bilimleri ve Uygulama, 8(15), 83-98.

Kılıççı, Y. (2006). Okulda ruh sağ lığ (5.Basım). İstanbul: Anı Yayıncılık.

Kılınç, M., \& Uzun, K. (2020a). The predictor role of the search for meaning in life in the determination of high school students' lifelong learning tendencies. International Journal of Psychology and Educational Studies, 7(3), 89-100. https://doi.org/10.17220/ijpes.2020.03.009

Kılınç, M., \& Uzun, K. (2020b). Ergenlerin yaşam doyumlarının yordayıcıları olarak direkt ve dolaylı akran baskısı. OPUS-Uluslararası Toplum Araştırmaları Dergisi, 16(28), 1241-1271. https://doi.org/10.26466/opus.748254 
Kırdök, O. (2010). Bilişsel bilgiyi işleme yaklaşımına göre geliştirilen mesleki karar verme programının sınanması (Yayımlanmamış doktora tezi). Çukurova Üniversitesi, Sosyal Bilimler Enstitüsü, Adana.

Kırdök, O., \& Boran, S. B. (2020). Lise öğrencilerinin mükemmeliyetçilik özelliklerinin mesleki kararsızlık düzeylerini yordayıcı gücünün incelenmesi. Turkish Studies - Educational Sciences, 15(4), 2757-2770. https://doi.org/10.47423/turkishstudies.43505

Krumboltz, J. D. (1992). The wisdom of indecision. Journal of Vocational Behavior, 41(3), 239-244. https://doi.org/10.1016/0001-8791(92)90025-U

Lee, S., Gray, M., \& Kim, M. (2021). A pathway model of emotionally-associated predictors of US college students' career indecision (Preprint). https://doi.org/10.31219/osf.io/5tyau

Luzzo, D. A. (1993). Value of career-decision-making self-efficacy in predicting career-decisionmaking attitudes and skills. Journal of Counseling Psychology, 40(2), 194-199. https://doi.org/10.1037/0022-0167.40.2.194

McInnes, T., \& Chen, C. P. (2011). Chronic career indecision: Amalgamate career development theories and action research perspectives. International Journal of Action Research, 7(1), 80-100.

Millî Eğitim Bakanlı̆̆ı [MEB] (2013). Millî Ĕ̆itim Bakanlı̆̆ı ortaöğretim kurumları yönetmeliği, Tarih: 07.09.2013, Sayı: 28758.

Mitchell, K. E., Al Levin, S., \& Krumboltz, J. D. (1999). Planned happenstance: Constructing unexpected career opportunities. Journal of Counseling $\mathcal{E}$ Development, 77(2), 115-124. https://doi.org/10.1002/j.1556-6676.1999.tb02431.x

Mutlu, T., Korkut-Owen, F., Özdemir, S., \& Ulaş-Kılıç, Ö. (2019). Beliren yetişkinlerin kariyer planları, yaşadıkları kariyer kararsızlıkları ve bununla baş etme stratejileri. Kariyer Psikolojik Danışmanlığı Dergisi, 2(1), 1-31.

Noeth, R. J., Engen, H. B., \& Noeth, P. E. (1984). Making career decisions: A self-report of factors that help high school students. Vocational Guidance Quarterly, 32(4), 240-248. https://doi.org/10.1002/j.2164-585X.1984.tb01587.x

Osipow, S. H. (1999). Assessing career indecision. Journal of Vocational Behavior, 55(1), 147-154. https://doi.org/10.1006/jvbe.1999.1704

Patton, W., \& McMahon, M. (1006). Career development and systems theory: A new relationship (2.Basim). Netharlands: Sense Publishers.

Sampson Jr, J. P., Peterson, G. W., Lenz, J. G., Reardon, R. C., \& Saunders, D. E. (1996). Career thoughts inventory: Professional manual. Odessa, FL: Psychological Assessment Resources.

Savickas, M. L. (1989). Annual review: Practice and research in career counseling and development, 1988. The Career Development Quarterly, 38(2), 100-134. https://doi.org/10.1002/j.2161-0045.1989.tb00415.x

Savickas, M. L. (1994). Measuring career development: Current status and future directions. The Career Development Quarterly, 43(1), 54-62. https://doi.org/10.1002/j.2161-0045.1994.tb00846.x

Sharf, R. S. (2013). Applying career development theory to counseling (6.Basim). Pacific Grove, CA: Brooks/Cole, Cengage Learning.

Siyez, D. M. (2013). Gelişimsel yaklaşımlar. B. Yeşilyaprak (Ed.), Mesleki rehberlik ve kariyer danışmanlığı: Kuramdan uygulamaya (4.Basım) içinde (ss. 171-217). Ankara: Pegem Akademi.

Super, D. E. (1980). A life-span, life-space approach to career development. Journal of Vocational Behavior, 16(3), 282-298. https://doi.org/10.1016/0001-8791(80)90056-1

Şeker, G., \& Kaya, A. (2019). Mesleki karar verme programının onuncu sınıf öğrencilerinin mesleki kararsızlık düzeyleri üzerinde etkililiğinin sınanması. Gazi Üniversitesi Gazi Ĕ̆itim Fakültesi Dergisi, 39(1), 457-476. 
Şeker, G. (2021). Kariyer kararsızlığının yordayıcısı olarak iyi oluş ve kariyer kaygısı. Pamukkale Üniversitesi Ĕ̆gitim Fakültesi Dergisi, (51), 262-275. https://doi.org/10.9779/pauefd.706983

Tokar, D. M., Withrow, J. R., Hall, R. J., \& Moradi, B. (2003). Psychological separation, attachment security, vocational self-concept crystallization, and career indecision: A structural equation analysis. Journal of Counseling Psychology, 50(1), 3-19. https://doi.org/10.1037/0022-0167.50.1.3

Varlık, S., \& Apaydın, C. (2020). The effect of career indecision on wrong choice of an occupation: A mixed methods research. Journal of Mixed Method Studies, 1(1), 75-91.

Yılmaz, N., \& Bedel, A. (2021). Lise öğrencilerinin mesleki kararsızlıklarını açıklamada kariyer denetim odağı ile meslek seçimine ilişkin akılcı olmayan inançların rolü. OPUS-Uluslararası Toplum Araştırmaları Dergisi, 17(34), 1023-1046. https://doi.org/10.26466/opus.800873 